\title{
Proposal of a non-lethal visual census method to estimate freshwater stingray abundance
}

\author{
Mónica Andrea Morales-Betancourt ${ }^{1}{ }^{*}$, Carlos Andrés Lasso Alcalá ${ }^{1}$
}

Edited by
Juan Carlos Salcedo-Reyes
(salcedo.juan@javeriana.edu.co)
Andrés Felipe Navia
(anavia@squalus.org)
1. Instituto de Investigación de
Recursos Biológicos Alexander
von Humboldt, Street 28a \#15-09
Bogotá, Colombia
* mmorales@humboldt.org.co
Received: 18-02-2015
Accepted: 13-11-2015
Published on line: 27-01-2016
Citation: Morales-Betancourt MA,
Lasso CA (2016) Proposal
of a non-lethal visual census
method to estimate freshwater
stingray abundance.
Universitas Scientiarum 21(1): 23-32
doi: 10.11144/Javeriana.SC21-1.poan
Funding: N/A
Electronic supplementary
material: N/A
open ACCEss

\section{Edited by}

Juan Carlos Salcedo-Reyes

Andrés Felipe Navia

1. Instituto de Investigación de Recursos Biológicos Alexander von Humboldt, Street 28a \#15-09

*mmorales@humboldt.org.co

Received: 18-02-2015

Accepted: 13-11-2015

Citation: Morales-Betancourt MA,

Lasso CA (2016) Proposal

method to estimate freshwate

stingray abundance.

Universitas Scientiarum 21(1): 23-32

Funding: N/A

Electronic supplementary

OPEN $(3)$ ACCES

\begin{abstract}
There is not a current method to estimate South American freshwater stingray's abundance. Therefore we designed a census method and tested it in the field. It consists of making nocturnal surveys by boat in large rivers ( $>25 \mathrm{~m}$ width) and floodplain lagoons of varying sizes, along transects of $100 \mathrm{~m} \times 10 \mathrm{~m}\left(1000 \mathrm{~m}^{2}\right)$. We applied this method in the Tomo River, a tributary of the Orinoco River in Colombia. 110 transects were surveyed in 200 runs. A total of 149 rays of four species were recorded: Potamotrygon motoro, Potamotrygon orbignyi, Potamotrygon schroederi and Paratrygon aiereba. P. motoro was the most abundant with a density of 0.31 individuals $/ 1000 \mathrm{~m}^{2}(\mathrm{SD}=0.5)$. This method gave optimal results when applied to habitats with high transparency and shallow depth $(<1 \mathrm{~m})$ since it permitted the identification of both adults and juveniles present.
\end{abstract}

Keywords: density; Potamotrygonidae; Orinoco river basin; Colombia.

\section{Introduction}

The family Potamotrygonidae is a complex taxonomic group of four genera: one monotypic genus (Paratrygon Dumeril 1865), two genera with two species respectively (Plesiotrygon Rosa, Castello and Thorson 1987 and Heliotrygon Carvalho and Lovejoy 2011), and one multispecies genus (Potamotrygon Garman 1877) that currently has roughly 20 nominal species (Carvalho et al. 2003, 2011, Fontenelle et al. 2014, Lasso et al. 2013a, Loboda \& Carvalho 2013, Rosa 1985, Rosa et al. 2010, Silva \& Carvalho 2011a-b). In Colombia, Peru, and Brazil; the family is of great importance as an ornamental fishery resource. This resource is in great demand in the international markets, and provides an important economic input to local communities. Due to the biological features of these fish (e.g. low fecundity, slow growth, partial parental care, late maturation, and annual or inter-annual reproduction), they are extremely vulnerable to human impacts and overharvesting (Lasso et al. 2013a). Thus, four of the eleven species of freshwater stingrays found in Colombia are classified as vulnerable: Paratrygon aiereba, Potamotrygon motoro, Potamotrygon schroederi and Potamotrygon yepezi (Mojica et al. 2012). The first three are found in the Amazon and Orinoco River Basin respectively, and the fourth is endemic to the Lake Maracaibo Basin (Lasso et al. 2013a). 
There are five species of importance in the Orinoco River Basin: the Motoro Ray (Potamotrygon motoro), the Common/Tiger Ray (Potamotrygon orbignyz), the Macaw Ray (Potamotrygon schroederi), the Manta River Ray (Paratrygon aiereba) and the Diamond Ray (Potamotrygon scobina) (Lasso et al. 2013a). These species are subjected to intense fishing by ornamental collectors throughout the basin. The fishery authorities annually establish an export quota for each species at a national level to regulate fishing. A difficulty confronted by the fishery authorities is the lack of information about adequate methods to estimate stingray abundance in the exploited areas. Therefore, it is fundamental to obtain baseline information about minimum population estimates to adequately inform authorities (i.e. who set the annual quotas). Methods to census fish by direct or subaquatic observation are widely used throughout the world in fresh waters (e.g. Helfman 1992, O’Neal 2007), in Neotropical freshwater ecosystems (e.g. Cassatti \& Castro 1998, Lasso et al. 2002, Nakamura et al. 2004, Sabino 1999, Sazima 1986, Teresa et al. 2011), and especially for the study of freshwater stingray behavior (Garrone Neto 2013, Garrone Neto \& Sazima 2009a-b, Garrone Neto \& Uieda 2009, 2012, Silva \& Uieda 2007), but no method exists to permit abundance estimation of these freshwater stingrays. With this goal, we designed and field tested one method to estimate stingray abundance. It was tested in the lower stretch of the Tomo River (Orinoco River basin, Colombia) during the dry season of 2014, with the objective to validate its utility and potential use in other rivers where environmental conditions are similar. Thusly, the objective of this study is to propose and describe a non-lethal visual method to estimate freshwater stingray abundance in clear waters.

\section{Materials and methods}

Study area

The Tomo River is located in the southeast region of Colombia, in Vichada Department. It originates in the Carimagua Lagoon located in Meta; flows from west to east through Vichada; and empties into the Orinoco River in the Tuparro National Natural Park (IGAC 1999) (Figure 1a). It has an approximate length of $606 \mathrm{~km}$ and drains the high plains that discharge clear waters in the sense of Sioli (1975). It receives several clear water tributary streams and floodplain lagoons. The physicochemical characteristics vary among aquatic habitats. The floodplain lagoon has alkaline waters with a $\mathrm{pH}$ of 8.7 , a conductivity of $83 \mu \mathrm{S}$, and a low measurement dissolved solids of $81 \mathrm{ppm}$; contrasting with the waters coming from the Tomo River that are acidic in $\mathrm{pH}(6.6)$, very low in conductivity $(3 \mu \mathrm{S})$ and dissolved solids (1 $\mathrm{ppm})$. The rainfall regime is unimodal with a dry season from December to March, and rains from April to November.

\section{Sampling}

This pilot project was carried out between February $23^{\text {rd }}$ and March $2^{\text {nd }}$ of 2014 during the low water period. The method was tested with nocturnal runs; using a boat in large rivers ( $>25 \mathrm{~m}$ width) and in floodplain lagoons (variable area). 110 transects were delimited during 200 runs (Table 1). During this time, the following three minimum conditions were met to allow the application of the census method: 1) the emergence of beaches in large rivers; 2) greater water transparency; and 3) lower water 

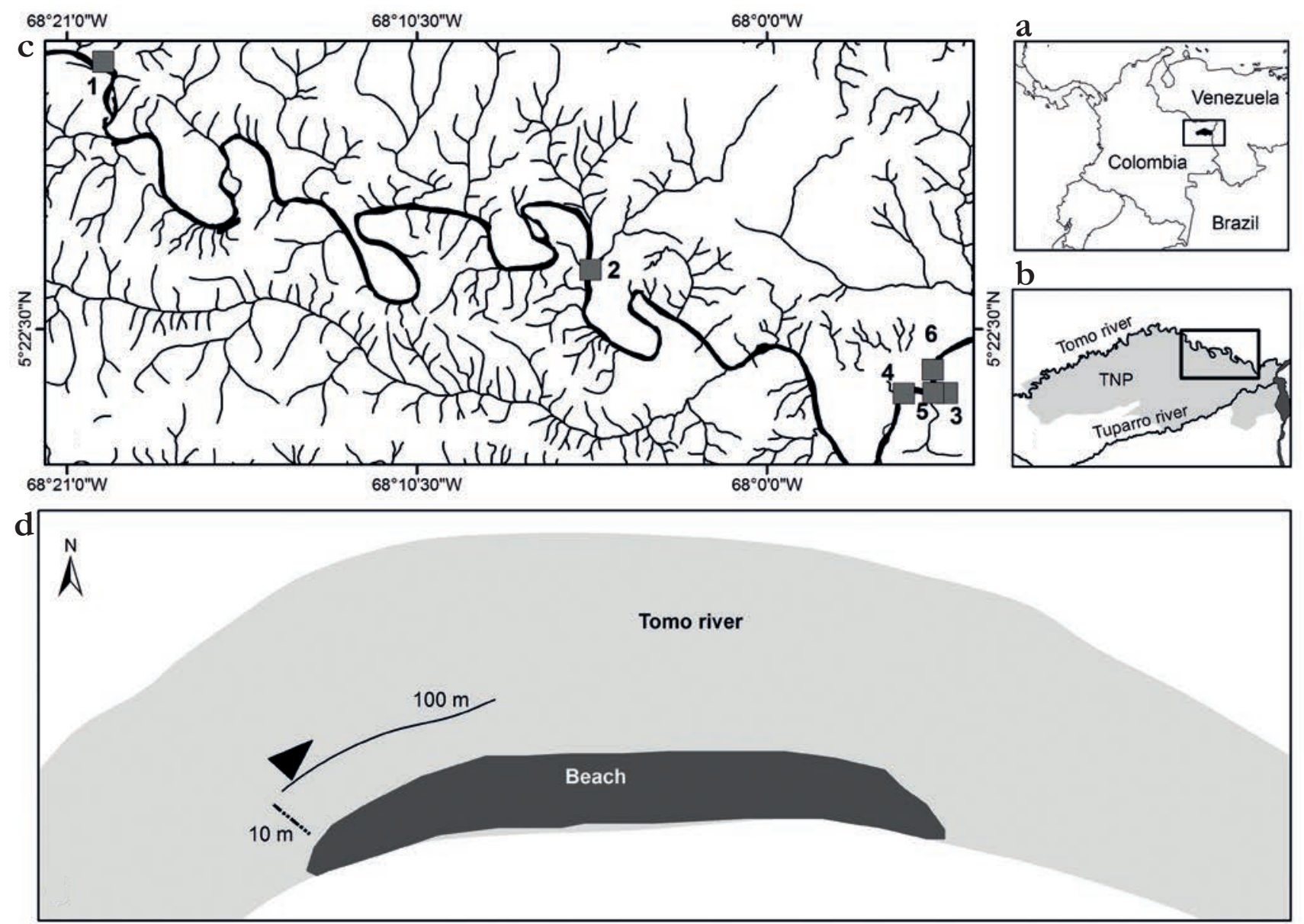

Fig. 1. Study area and transect model location. a) Location of Tuparro National Park (TNP); b) detail of sampling area; c) sampling stations: 1) floodplain lake I, 2) floodplain lake II, 3) floodplain lake III, 4) large river (beach I), 5) large river (beach II), 6) large river (beach III); and d) location of transect model in river channel.

levels yielding shallower water depths and less extensive flooded areas. The censuses were done in the lower section of the Tomo River (Figure 1b) where the following aquatic environments were evaluated: 1) large river (3 sites), and 2) floodplain lagoons (3 sites) (Figure 1c). Species were identified and the development stages were based

Table 1. Summary of sampling effort by habitat.

\begin{tabular}{|c|c|c|c|}
\hline Site & $\begin{array}{l}\text { Number of transects } \\
\qquad(100 \mathrm{~m} \times 10 \mathrm{~m})\end{array}$ & $\begin{array}{l}\text { Number of runs } \\
\text { per transect }\end{array}$ & $\begin{array}{c}\text { Total } \\
\text { runs/site }\end{array}$ \\
\hline Floodplain lake I & 20 & 2 & 40 \\
\hline Floodplain lake II & 20 & 2 & 40 \\
\hline Floodplain lake III & 30 & 2 & 60 \\
\hline Large river (beach I) & 10 & 1 & 10 \\
\hline Large river (beach II) & 20 & 2 & 40 \\
\hline Large river (beach III) & 10 & 1 & 10 \\
\hline Total & 110 & 10 & 200 \\
\hline
\end{tabular}


on the work of Charvet-Almeida et al. (2005), Lasso et al. (2013a, b, c, d, e), Loboda \& Carvalho (2013), Rosa (1985), and Silva \& Carvalho (2015).

A detailed description of this proposed census method is given in the Results section.

Data analysis

For our proposed method, the density was calculated for each species, as well as their respective standard deviations (SD) and percent coefficients of variance (CV).

$$
\text { Density }=\text { number of individual } / 1000 \mathrm{~m}^{2}
$$

\section{Results}

\section{Description of method}

Three people are needed for this type of census: one observer, one recorder, and one boat operator. To begin the census, the driver must turn off the motor and proceed using a paddle or pole to avoid perturbation of the area. The boat should be, at maximum, $10 \mathrm{~m}$ from the shore (i.e. the maximum effective area of visibility of the observer). The observer is located at the bow with a field of observation from the boat to shore. Flashlights or headlamps are used to detect eye shine (red or yellow in stingrays) or the outline of the bodies of the stingrays sitting on the bottom. Upon observation of a stingray, the boat moves as close as necessary to permit species identification, size estimation (disc width), and maturity (adult or juvenile). Rays can be identified by the color pattern that is distinctive for each species. The recorder notes all the pertinent information at the initiation point of the run: time, date, geographic coordinates and site name and description; then records the time of each observation (meters travelled, coordinates, time, number of individuals, species, estimated size, and developmental state) and again at the end of the run the time, meters travelled and coordinates. Each transect was $100 \mathrm{~m}$ long $* 10 \mathrm{~m}$ wide $\left(1000 \mathrm{~m}^{2}\right)$ (Figure 1d).

\section{Results of pilot test (census)}

A total of 149 stingrays were recorded, of four species: Potamotrygon motoro (62 individuals), Potamotrygon orbignyi (57), Paratrygon aiereba (18) and Potamotrygon schroederi (12) (Figure 2). Both juveniles and adults were observed, with a predominance of juveniles in all species. Sympatric and syntopic distribution of four species of stingrays was recorded (all four species in one beach). In Table 2 , the density of each species is shown, along with the standard deviation and coefficient of variance.

Potamotrygon motoro had the highest relative abundance values, followed by P. orbignyi, Paratrygon aiereba and P. schroederi. The high values and differences in SD and CV for P. schroederi and P. aiereba are probably due to spatial variation in the distribution of species since these two were only observed in the main channel of the river. The other two species, P. motoro and P. orbignyi, were observed both in rivers and lagoons, and had high density values and slightly lower coefficients of variance. 

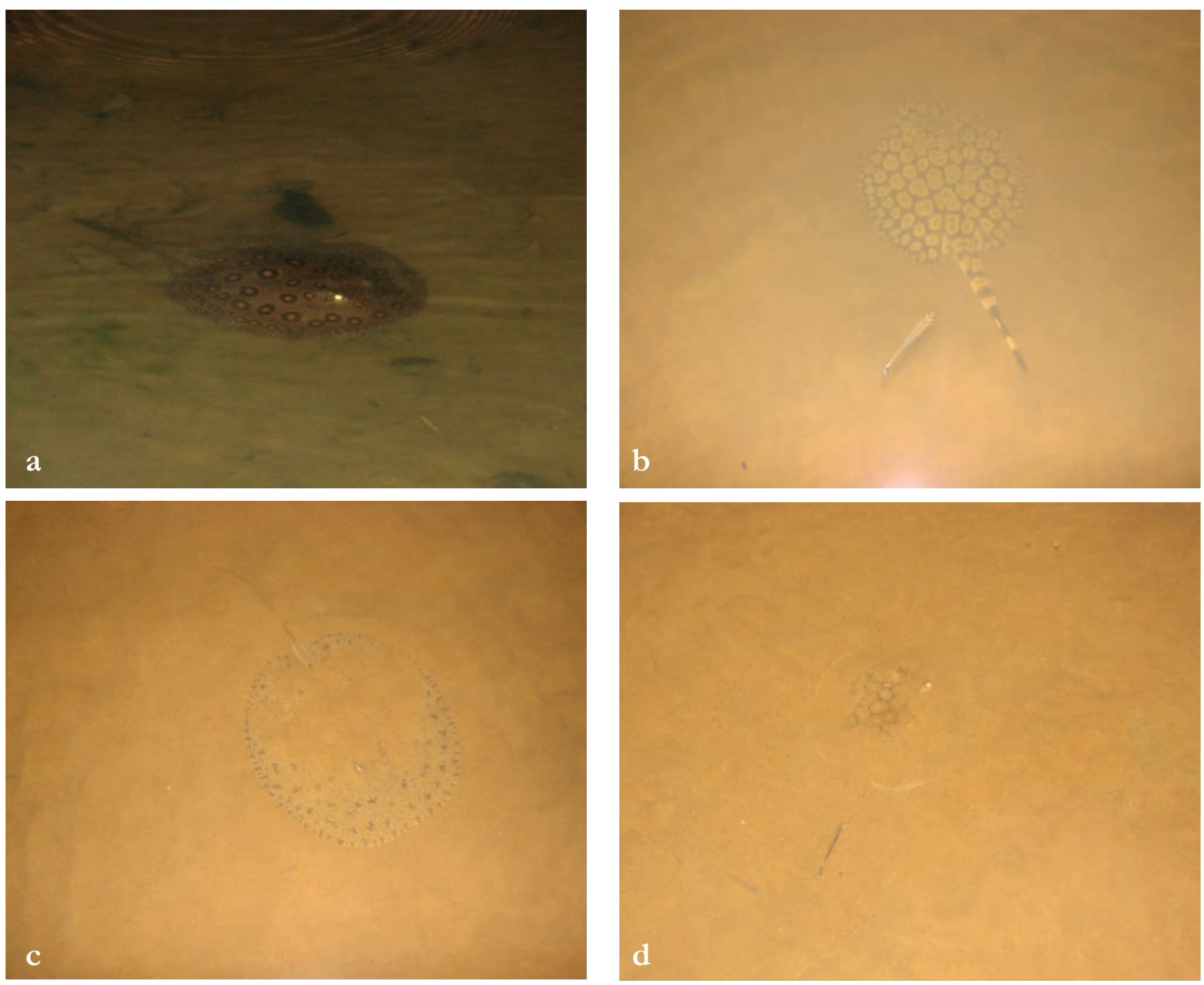

Fig. 2. Sightings of rays during the nocturnal sampling in the Tomo River: a) Potamotrygon motoro; b) Potamotrygon scbroederi; c) Paratrygon aiereba; d) Potamotrygon orbignyi.

\section{Discussion}

This method is recommended for large rivers and floodplain lagoons with beaches where water depth during the dry season depth is not greater than 1 meter. This permits sampling along greater distances (longer transects) and different habitats in less time. The detection capability was good (using a maximum distance from shore

Table 2. Density (D) (ind./1000 $\mathrm{m}^{2}$ ). SD: standard deviation. CV: coefficient of variance (SD/D*100). $\mathrm{n}=149$.

\begin{tabular}{lcccc}
\hline Species & $\mathbf{n}$ & $\mathbf{D}$ & $\mathrm{SD}$ & $\mathrm{CV}$ \\
\hline Paratrygon aiereba & 18 & 0.09 & 0.2 & 224.4 \\
Potamotrygon motoro & 62 & 0.31 & 0.5 & 161.3 \\
Potamotrygon orbignyi & 57 & 0.29 & 0.43 & 148.2 \\
Total & 149 & & & \\
\hline
\end{tabular}


of $10 \mathrm{~m}$ ). The information obtained by this method also allows better understanding of the habitat preference, size, and behavior of the rays observed. It is also a safe and comfortable method for the researchers doing the work. For these nocturnal surveys, the lunar cycle should be taken into account, since it will affect visibility and the ability of the observer to detect the eye shine of the rays. The observer's effectiveness diminishes based on the environment being illuminated by the moon. The lunar cycle may also affect the behavior of the rays. As would be expected, proper depth is crucial for best observation. A maximum of $1 \mathrm{~m}$ water depth was found optimal under field conditions encountered during this pilot test. Turbidity and wind (affecting the surface of the water) can affect the ability of observation, as well as the behavior of the stingrays; there should be caution taken to minimize their impact on the census.

We found that this method permits data collection, not only on the abundance of the species, but also generates information about the population structure if the development stage can be observed (adult vs. juvenile). The advantage of nocturnal observation is that it permits the observer to see and quantify the number of neonates and juveniles, that during the day, stay in the deeper parts of their habitat, and adults that migrate at night towards the beaches on shore from the deeper waters of the main channel. This has been shown for P. motoro and P. falkneri in the upper Paraná River basin by Garrone Neto \& Uieda (2012).

This method requires only a basic taxonomic knowledge of the species identified when their eyes reflect light back from spotlights used to observe them and can easily be replicated by other researchers in rivers and lagoons with the physical conditions described above. We were able to observe and differentiate neonates, juveniles, and adults. The presence of young may indicate that these populations are in good condition. It is important to mention that the ornamental fishery is selective towards neonates and juveniles, and undertaken only during low water phase; the same time of year we carried out our method trials. Theoretically, little or no ornamental fishing pressure is present in this stretch of the river, since neonates and juveniles are the most sought after specimens (Lasso et al. 2013a). This method also permits observations of behavior and activity rhythms, and complements other methods based on underwater observations (Garrone Neto 2013, Garrone Neto \& Sazima 2009a-b, Garrone Neto \& Uieda 2009, 2012, Silva \& Uieda 2007).

Our relative abundance values can not be classified as high or low since there is no comparative values available in literature and we have few replicates. This is the first data published, and as they were obtained in a protected area with no ornamental fishing, they do provide a baseline for comparison with areas where that activity does occur.

\section{Conclusions}

The method was designed to estimate freshwater stingray's abundance and field testing proved to be feasible, easily applied, and economical. Furthermore, it does not require significant technical preparation, an important factor since the objective is to provide the fishery or environmental governmental authorities with the means to implement the census using technicians with only basic training. This method was useful both on 
beaches and shorelines of the main river channel and floodplain lagoons; both areas where ornamental fishers catch stingrays. Successful use will depend upon the physical conditions of the areas sampled (water transparency, depth, etc.). We recommend using the method only at night because, during the day, the results may be different if we consider the activity patterns of the species. Finally, it is important to remember that the objective of this study was not to obtain estimations of the abundance of the stingrays present in the study area, but to propose and test a census method to determine its potential usefulness in other similar aquatic ecosystems. This is the first time that this method has been tested and additional testing needs to continue in the future in order to assess its validity.

\section{Acknowledgements}

We thank the following institutions for assistance: Parque Nacionales Naturales de Colombia, Wildlife Conservation Society, Instituto de Investigación de Recursos Biológicos Alexander von Humboldt and the Asociación Red Colombiana de Reservas Naturales de la Sociedad Civil for supporting our project. We also thank Wilson Aya (an ornamental fisherman) and the park rangers of the Tuparro PNN, Ariel Trujillo and José Luis Rueda for their help in recording information in the field. We also thank Orlando Patiño (PNN Tuparro) and Isaac Goldstein (WCS) for all their help. To Guillermo Bianchi for his contribution to data analysis. And, to Donald Taphorn for the translation of this manuscript.

\section{Conflicts of interest}

The authors declare that there are no conflicts of interest.

\section{References}

Carvalho MR, Lovejoy NR, Rosa R (2003) Family Potamotrygonidae. In: Reis, RE, Ferraris Jr. CJ, Kullander SO (eds.) Check List of the Freshwater Fishes of South and Central America. EDIPUCRS, Porto Alegre, Brazil, pp 22-29

Carvalho MR, Sabaj-Pérez M, Lovejoy NR (2011) Potamotrygon tigrina, a new species of freshwater stingray from the Upper Amazon basin, closely related to Potamotrygon schroederi Fernández-Yépez 1958 (Chondricthyes: Potamotrygonidae). Zootaxa 2827:1-30

Cassatti L, Castro M (1998) A fish community of Sao Francisco River headwater riffles, southeastern Brazil. Ichthyological Exploration Freshwater 9:229-242

Charvet P, Araújo ML, Almeida M (2005) Reproductive aspects of freshwater stingrays (Chondrichthyes: Potamotrygonidae) in the Brazilian Amazon basin. Journal Nortbwestern Atlantic Fisheries Sciences 35:165-171

doi: 10.2960/J.v35.m502

Fontenelle JP, Silva JP, Carvalho MR (2014) Potamotrygon limai, sp. nov., a new species of freshwater stingray from the Upper Madeira River system, Amazon basin (Chondrichthyes: Potamotrygonidae). Zootaxa 3765:249-268 doi: 10.11646/zootaxa.3765.3.2

Garrone-Neto D (2013) Utilización de métodos no letales para el estudio de las rayas de agua dulce (Potamotrygonidae). In: Lasso CA, Rosa RS, Sánchez-Duarte P, MoralesBetancourt MA, Agudelo-Córdoba E (eds). IX. Rayas de agua dulce (Potamotrygonidae) de Suramérica. Parte I. Colombia, Venezuela, Ecuador, Perú, Brasil, Guyana, Surinam y Guayana Francesa: diversidad, bioecología, uso y conservación. Serie Editorial Recursos Hidrobiológicos y Pesqueros Continentales de Colombia. Instituto de Investigación de Recursos Biológicos Alexander von Humboldt (IAvH). Bogotá, D. C., Colombia, pp 85-95 
Garrone Neto D, Sazima I (2009a) Stirring, charging, and picking: hunting tactics of potamotrygonids rays in upper Parana River. Neotropical Icbtbyology 7:113-116 doi: 10.1590/S1679-62252009000100015

Garrone Neto D, Sazima I (2009b) The more stirring the better: cichlid fishes associate with foraging potamotrygonids rays. Neotropical Ichthyology 7:499-501-

doi: 10.1590/S1679-62252009000300018

Garrone Neto D, Uieda VS (2009) Ingestion of catfish by freshwater stingray: possible mistake or inexperience. Biota Neotropica 9:1-3

doi: 10.1590/S1676-06032009000400029

Garrone Neto D, Uieda VS (2012) Activity and habitat use of two species of stingrays (Myliobatiformes: Potamotrygonidae) in the upper Paraná River basin, Southeastern Brazil. Neotropical Icbthyology 10:81-88

doi: 10.1590/S1679-62252012000100008

Helfman, GS (1992) Underwater methods. In: Nielsen LA, Johnson DL (eds.) Fisheries Techniques. Blacksburg, American Fisheries Society, USA, pp 349-369

IGAC-Instituto Geográfico Agustín Codazzi (1999) Paisajes Fisiográficos Orinoquia Amazonia (ORAM) Colombia. Ministerio de Hacienda y Crédito Público, Colombia.

Lasso CA, Lasso-Alcalá OM, Meri J (2002) Diversidad y estructura de la comunidad de peces de un río de la Guayana venezolana: observaciones y censos subacuáticos como metodología alternativa. Memoria de la Fundación La Salle de Ciencias Naturales 154:99-115

Lasso CA, Rosa RS, Sánchez-Duarte P, Morales-Betancourt MA, Agudelo-Córdoba E (eds) (2013a) IX. Rayas de agua dulce (Potamotrygonidae) de Suramérica. Parte I. Colombia, Venezuela, Ecuador, Perú, Brasil, Guyana, Surinam y Guayana Francesa: diversidad, bioecología, uso y conservación. Serie Editorial Recursos Hidrobiológicos y Pesqueros Continentales de Colombia. Instituto de Investigación de Recursos Biológicos Alexander von Humboldt (IAvH). Bogotá, D. C., Colombia

Lasso CA, Sánchez-Duarte P, Barbarino A, Morales-Betancourt MA, Ortiz-Arroyave LM, Lasso-Alcalá OM (2013b) Paratrygon aiereba (Orinoco). In: Lasso CA, Rosa RS, SánchezDuarte P, Morales-Betancourt MA, Agudelo-Córdoba E (eds). IX. Rayas de agua dulce (Potamotrygonidae) de Suramérica. Parte I. Colombia, Venezuela, Ecuador, Perú, Brasil, Guyana, Surinam y Guayana Francesa: diversidad, bioecología, uso y conservación. Serie Editorial Recursos Hidrobiológicos y Pesqueros Continentales de Colombia. Instituto de Investigación de Recursos Biológicos Alexander von Humboldt ( $\mathrm{IAvH})$. Bogotá, D. C., Colombia, pp 137-150

Lasso CA, Sánchez-Duarte P, Morales-Betancourt MA, Ortiz- Arroyave LM, Lasso-Alcalá OM (2013c) Potamotrygon motoro (Orinoco). In: Lasso CA, Rosa RS, Sánchez-Duarte P, MoralesBetancourt MA, Agudelo-Córdoba E (eds.) IX. Rayas de agua dulce (Potamotrygonidae) de Suramérica. Parte I. Colombia, Venezuela, Ecuador, Perú, Brasil, Guyana, Surinam y Guayana Francesa: diversidad, bioecología, uso y conservación. Serie Editorial Recursos Hidrobiológicos y Pesqueros Continentales de Colombia. Instituto de Investigación de Recursos Biológicos Alexander von Humboldt (IAvH). Bogotá, D. C., Colombia, pp 209217

Lasso CA, Sánchez-Duarte P, Morales-Betancourt MA, Ortiz-Arroyave LM, Agudelo J (2013d) Potamotrygon orbignyi. In: Lasso CA, Rosa RS, Sánchez-Duarte P, Morales-Betancourt MA, Agudelo-Córdoba E (eds.) IX. Rayas de agua dulce (Potamotrygonidae) de Suramérica. Parte I. Colombia, Venezuela, Ecuador, Perú, Brasil, Guyana, Surinam y Guayana Francesa: diversidad, bioecología, uso y conservación. Serie Editorial Recursos Hidrobiológicos y Pesqueros Continentales de Colombia. Instituto de Investigación de Recursos Biológicos Alexander von Humboldt (IAvH). Bogotá, D. C., Colombia, pp 228-246 
Lasso CA, Sanchez-Duarte P, Lasso-Alcala OM, Ortiz-Arroyave LM, Morales-Betancourt MA, et al. (2013e) Potamotrygon schroederi. In: Lasso CA, Rosa RS, Sánchez-Duarte P, MoralesBetancourt MA, Agudelo-Córdoba E (eds.) IX. Rayas de agua dulce (Potamotrygonidae) de Suramérica. Parte I. Colombia, Venezuela, Ecuador, Perú, Brasil, Guyana, Surinam y Guayana Francesa: diversidad, bioecología, uso y conservación. Serie Editorial Recursos Hidrobiológicos y Pesqueros Continentales de Colombia. Instituto de Investigación de Recursos Biológicos Alexander von Humboldt (IAvH). Bogotá, D. C., Colombia, pp 247- 255

Loboda T, Carvalho M (2013) Systematics revision of Potamotrygon motoro (Muller and Henle, 1841) species complex in the Paraná-Paraguay basin, with descriptions of two new ocellated species (Chondrichthyes: Myliobatiformes: Potamotrygonidae). Neotropical Ichthyology 11(4):693-737

doi: 10.1590/S1679-62252013000400001

Mojica JI, Usma JS, Álvarez-León R, Lasso CA (eds.) (2012) Libro rojo de peces dulceacuícolas de Colombia 2012. Instituto de Investigación de Recursos Biológicos Alexander von Humboldt, Instituto de Ciencias Naturales de la Universidad Nacional de Colombia, WWF Colombia y Universidad de Manizales. Bogotá, Colombia

Nakamura K, Lasso CA, Vispo C, Ortaz M (2004) Observaciones subacuáticas: una herramienta efectiva para la obtención de datos ecológicos y etológicos en comunidades ícticas continentales. Memoria de la Fundación La Salle de Ciencias Naturales 157:83-110

O’Neil JS (2007) Snorkel Surveys. In: Johnson DH, Shrier BM, O’Neal JS, Knutzen JA, Augerot X, O’Neil TA, Pearsons TN (eds.) Salmonid Field Protocols Handbook: Techniques for Assesing Status and Trends in Salmon and Trout Populations. Bethseda: The American Fisheries Society in association with State of the Salmon, USA, pp 325-340

Rosa R (1985) A systematic revision of the South American freshwater stingrays (Chondrichthyes: Potamotrygonidae). Doctorate thesis. The College of William and Mery, Williamsburg, USA

Rosa R, Charvet P, Quijada CD (2010) Biology of the South American potamotrygonid stingrays. In: Carrier JC, Musik JA, Heithaus MR (eds) Shark and their relatives II: Biodiversity, adaptative physiology, and conservation. CRC Press, Boca de Ratón, pp 241-285

Sabino J (1999) Comportamento de peixes em riachos: uma abordagem naturalística. In: Caramaschi EP, Mazzoni R, Peres-Neto PR (eds) Ecologia de peixes de riachos. Rio de Janeiro, PPGE-UFRJ, Brazil, pp 183-208

Sazima I (1986) Similarities in feeding behaviour between some marine and freshwater fishes in two tropical communities. Journal of Fish Biology 29:53-65

doi: 10.1111/j.1095-8649.1986.tb04926.x

Silva JP, Carvalho, M (2011a) A taxonomic and morphological redescription of Potamotrygon falkneri Castex \& Maciel , 1963 (Chondrichthyes: Myliobatiformes: Potamotrygonidae). Neotropical Ichtbyology 9 (1):209-232

doi: 10.1590/S1679-62252011000100021

Silva JP, Carvalho, M (2011b) A new species of Neotropical freshwater stingray of the genus Potamotrygon Garman, 1877 from the Río Madre de Dios, Perú (Chondrichthyes: Potamotrygonidae). Papéis Avulsos de Zoologia 51(8):139-154

doi: 10.1590/S0031-10492011000800001

Silva JP, Carvalho, M (2015) Systematics and morphology of Potamotrygon orbignyi (Castelnau 1855) and allied forms (Chondrichthyes: Myliobatiformes: Potamotrygonidae). Zootaxa 3982(1):1-82

doi: $10.11646 /$ zootaxa.3982.1.1 
Silva, TB, Uieda VS (2007) Preliminary data on the feeding habits of the freshwater stingrays Potamotrygon falkneri and Potamotrygon motoro (Potamotrygonidae) from the Upper Paraná River basin, Brazil. Biota Neotropica 7:183-188 doi: 10.1590/S1676-06032007000100027

Sioli H (1975) Tropical rivers as expressions of their terrestrial environment. In: Goley F, Medina E (eds) Tropical Ecological System. Trend in Terrestrial and Aquatic Research. Springer-Verlag, New York, pp 275-288 doi: 10.1007/978-3-642-88533-4_19

Teresa FB, Romero RM, Casatti L, Sabino J (2011) Habitat simplifications affects nuclearfollower foraging association among stream fishes. Neotropical Icbthyology 9:121-126 doi: 10.1590/S1679-62252011005000009

Propuesta metodológica no letal para la estimación visual de abundancia de rayas de agua dulce

Resumen. No existe actualmente un método para estimar la abundancia de las rayas suramericanas de agua dulce. Por ello se diseño un método para censarlas y se probó en campo. Consiste en hacer recorridos nocturnos en bote por ríos grandes (>25 $\mathrm{m}$ de ancho) y lagunas inundables de diversos tamaños, a lo largo de transectos de $100 \mathrm{~m}$ x $10 \mathrm{~m}\left(1000 \mathrm{~m}^{2}\right)$. Con este método se muestreó el río Tomo, un tributario del río Orinoco en Colombia. Se muestrearon 100 transectos en 200 recorridos. Se registró un total de 149 rayas pertenecientes a cuatro especies: Potamotrygon motoro, Potamotrygon orbignyi, Potamotrygon schroederi and Paratrygon aiereba. P. motoro fue la más abundante, con una densidad de 0.31 individuos $/ 1000 \mathrm{~m}^{2}$ (DE=5.06). Este método dio óptimos resultados cuando se aplicó a hábitats con alta transparencia y poca profundidad $(<1 \mathrm{~m})$, ya que así es posible identificar tanto a los adultos como a los juveniles presentes.

Palabras clave: densidad; Potamotrygonidae; cuenca del Orinoco; Colombia.

Proposta de um método de censo visual não letal para estimar de abundancia de raias de agua doce

Resumo. Não há um método atual para estimar a abundancia de raias de água doce Sul-Americanas, assim que desenhamos um método de censo e o testamos em campo no rio Tomo, um afluente do rio Orinoco, em Colômbia. Este método consiste na realização de levantamentos noturnos por barco em grandes rios ( $>25 \mathrm{~m}$ de margem) e lagoas de várzea de tamanhos diversos, usando um transecto de $100 \mathrm{~m} \times 10 \mathrm{~m}\left(1000 \mathrm{~m}^{2}\right)$. Em um total de 200 percursos, 110 transectos foram pesquisados. Um total de 149 raias de quatro espécies foram registradas: Potamotrygon motoro, Potamotrygon orbignyi, Potamotrygon schroederi e Paratrygon aiereba. P. motoro foi a mais abundante, com uma densidade de 0,31 indivíduos $/ 1000 \mathrm{~m}^{2}$ e um desvio padrão (DP) de 5,06. Este método forneceu os melhores resultados quando aplicado a habitats com alta transparência e baixa profundidade $(<1 \mathrm{~m})$ uma vez que permite a identificação de espécies tanto adultas quanto jovens.

Palavras-chave: densidade; Potamotrygonidae; bacia do Rio Orinoco; Colômbia.

Monica Andrea Morales Betancourt

Is a Biologist graduated from the Pontificia Universidad Javeriana with a master's degree from the Jorge Tadeo Lozano University, both in Bogotá, Colombia. She is currently a research scientist at the Alexander von Humboldt Biological Resources Research Institute in the field of Hydrobiology, Fisheries and Wildlife. Her work includes conservation (research, planning and administration) of aquatic biodiversity, especially freshwater stingrays, turtles and crocodiles.

Carlos Andres Lasso Alcalá

Earned his five year with thesis undergraduate degree (Licenciado) in Biology with a major in zoology from the Universidad Central de Venezuela in 1989; obtained a specialization in Fluvial Limnology (INALI-Conicet) in Argentina in 1992; and a doctorate in Biological Sciences (Ecology) from the University of Sevilla, Spain in 1996. He currently works at the Alexander von Humboldt Biological Resources Research Institute in Bogotá, Colombia, where he coordinates research in hydrobiology, fisheries and wildlife. 